\title{
Study and Practice of Entrepreneurial Talent Training Model in Automotive Service Field
}

\author{
Peijiang Chen \\ School of Automobile, Linyi University, Shandong, 276000, China \\ chenpeijiang@163.com
}

Keywords: Automotive service, Entrepreneurial talents, training model, innovation spirit

\begin{abstract}
In order to meet the development needs of automotive industry, the training model of entrepreneurial talent in the automotive service field is researched. The connotation of entrepreneurship education is understood deeply, lessons of talent training at home and abroad are summarized, the characteristics of regional economic development of Linyi city is combined. The automobile specialties, including vehicle engineering, automotive service engineering of Linyi University are taken as implementation focus, the entrepreneurial talent training model and system are built. The research object is to cultivate high quality applied talents with professional knowledge and skills, management abilities, high innovation spirit and entrepreneurial ability.
\end{abstract}

\section{Introduction}

With the social and economic development, the personnel training requirements of colleges are changing and improving. The training of students' innovation and entrepreneurship is a strategic issue, which is an important task for high education personnel training whether it has innovative entrepreneurship, adapts to economic and social development, and realizes the national revitalization.

The government of China supports the entrepreneurship. Correspondingly, the colleges and universities are vigorously carrying out the innovation and entrepreneurship education to improve the employability of students.

The innovation and entrepreneurship education originated from the developed countries in Europe and America [1]. In 1983, the first college entrepreneurship competition was held in University of Texas at Austin, which received much attention from the society. The innovation and entrepreneurship education in Chinese higher education originated from the business plan competition sponsored by Tsinghua University in 1997. In 2002, the Ministry of education determined nine universities to be pilot colleges for entrepreneurship education, exploring the basic methods and development modes of Chinese college student entrepreneurial education. Many universities in China set up pilot experimental classes to carry out the entrepreneurial training [2-4].

These studies have made very good exploration on entrepreneurial training model, but have defects in professional combination and students coverage scope. As the elite school of application oriented talent training characteristics in Shandong province, Linyi university, with the aim of national well-known, distinctive regional characteristics of innovation and entrepreneurial university, strives to cultivate high-quality application-oriented talents with solid theoretical foundation, innovative spirit and ability, Yimeng spirit and international vision. Accordingly, this study made the automotive service industry as the research field. The personnel training model was analyzed, and the students of auto majors were relied on to be practiced.

According to the student characteristics of automotive service engineering specialty and vehicle engineering specialty, facing automotive application and automotive service industry, this study reformed comprehensively in the personnel training system, curriculum, teaching methods, student extracurricular activities and entrepreneurship, trained high-quality talents with management ability, adapting to automotive service technology, high innovation spirit, entrepreneurship quality and ability in automotive service industry. 


\section{Cultivation conception of Entrepreneurial Talent Training in Automotive Service Field}

\section{Reform orientation of talent training mode}

In a large sense, the entrepreneurship education is to cultivate creative personnel with pioneering spirit, pioneering consciousness, entrepreneurial ability, social and management ability [5]. As an integral part of the college quality education, student entrepreneurship education is a kind of education idea and education mode of employment, and is the general education of entrepreneurship awareness, entrepreneurship spirit and entrepreneurship ability. It can not only train the entrepreneurial talent, but also enable students to learn how to acquire and create new knowledge, transform knowledge into real personal value and social value, and achieve maximum utility of knowledge

Since the automobile is a high-tech mechanical and electrical integration product, automotive service education has significant features of multi-disciplinary, strong skills, many types of student jobs and large talent demand [6]. The training aim of automotive service field is to cultivate entrepreneurial and applied talents of all round development, solid foundation, broad knowledge, high overall quality facing automotive service industry, based on Lunan Economic Belt.

\section{Reform thought of talent training mode}

Relying on the construction of automobile related specialties, taking the course system and course construction as the main content, through optimizing curriculum system, strengthening the practical education, entrepreneurship education and entrepreneurship practice, to strengthen school-enterprise communication and improve students' entrepreneurial capacity in the automotive service industry

The entrepreneurial talent training of automotive service field is to strive to achieve academic science and technology capacity-building, combination of professional competence and entrepreneurship culture, so as to make the students become modern science and technology talent of deep academic knowledge, solid foundation, strong practical ability and good at innovation.

The main idea of reform thought of talent training is to maintain and continue the features of strong technical skills and manual ability, adapt to the development of automotive service technology, strengthen the professional base and quality of students, broaden the culture caliber, cultivate compound and applied talent with multi-disciplinary knowledge, vigorously implement innovation and entrepreneurship education, and train new talents with science, professional and entrepreneurial ability.

\section{Training objective of entrepreneurial talent}

The training objective of entrepreneurial talent is to cultivate entrepreneurial and applied talents of all-round development, solid basic theory, having Yimeng spirits and international perspective. The students can master systematically the related knowledge and skill of automotive service field, meet the needs of modern automotive development, absorb and use modern production and service concept, qualified for automotive product design services, automotive production services, automotive sales service, automotive technology services, automotive transport services, automotive assessment, insurance claims and other automotive service jobs.

The cultivated talent has the following characteristics: Yimeng spirits, strong professional basis, the knowledge and competence feature of compound talents and meeting the diverse talent needs of professional fields, strong practical ability, and being good at innovation and entrepreneurship.

\section{The Implementation of Entrepreneurial Talent Training in Automotive Service Field}

The entrepreneurial talent training model of automotive service field is researched and practiced, and the main implementation policies are brought forward as follows.

\section{Optimize the course structure and build entrepreneurship education curriculum system}

The compulsory course hour should be compressed, and the elective course hour should be increased. According to knowledge structure requirement of entrepreneurial, knowledge updating speed and the related course, the curriculum system is adjusted. 
The modular curriculum system should be built up centering on the professional goal based on entrepreneurial ability cultivation. Every module progressives, mutually supports, organically combines, and highlights new and special feature of business module. In addition to accepting the necessary basic education and professional knowledge, students can freely select courses to achieve the object of individuals and personality development.

The curricular and extracurricular, in and out of school, term and holidays should be overall considered to create scientific and technological practice, entrepreneurship design, entrepreneurship practice and award credits for extracurricular activities.

\section{Improve teaching mode and strengthen the creative ability cultivation}

The teaching method reform should be actively promoted with classroom teaching as the core. By conducting open class and demonstration class, the case analysis and practice teaching are highlighted, simulation teaching, situational teaching, heuristic teaching and interactive teaching methods are used. The cultivation of entrepreneurship and creativity abilities is focused on.

The teaching information construction should be actively promoted focused on multimedia and network teaching. The teachers are encouraged and subsidized to develop courseware creating conditions, and required to select reasonable teaching methods, effectively use multimedia teaching, strengthen teaching network resource construction and actively promote network assisted teaching according to education law and course characteristics.

The examination form should be reformed and the scientific evaluation system should be established. The teachers are encouraged to reform assessment methods according to course characteristics, flexibly use course papers, research reports, design work and auxiliary examination forms based on rigorous written examination. The usual classroom discussion, questions, assignments and practical operation are all considered into students' achievement. Assessment methods can enhance students' interest in independent study, provide space for personality development, expand students' knowledge, and culture entrepreneurial ability and entrepreneurial awareness.

\section{Optimize practice teaching link and improve engineering innovation capability}

In the automotive specialties, there are many practical aspects, such as metalworking practice, professional recognizing practice, vehicle driving practice, course design for market research and service planning, maintenance equipment, automotive technology service, graduating practice, and so on.

In holidays, the students are organized to go deep into various types of automotive service industry, understand the entrepreneurial process and business conditions, and write investigation report. The investigation can make students feel difficult on entrepreneurship, and learn some entrepreneurial skills in the relevant fields

\section{Strengthen ideological education and cultivate entrepreneurial qualities}

It should strengthen the main channel education, give full play to the leading role of classroom teaching in moral education, enhance social responsibility of college students, and culture students' unity of moral cognition and practice.

The college students' good entrepreneurial psychological quality should be developed. The school can invite successful entrepreneurs to communication face to face with students, allow them to share their entrepreneurial experience, stimulating students' interest in entrepreneurship and enhancing the entrepreneurial enthusiasm and initiative.

The education should raise the students' awareness of knowledge industry, stimulate inner needs and motivations of entrepreneurship, develop entrepreneurial interest and pride, establish entrepreneurial ideas and beliefs. These measures can make students have psychological quality of dare to put into practice, and improve mental endurance.

The strong atmosphere of automotive culture is created for students to provide good conditions and environment. The school can invite experienced persons as teachers and counselors, invite celebrities and experts to hold entrepreneurial knowledge seminar, so as to broaden students' horizons and thinking space, develop students' humanistic and scientific quality, entrepreneurial spirit and ability. 


\section{Carry out entrepreneurship practice and experience}

By using the platform of Business Plan Competition, the students plan their own business from funding sources, business establishments, employee division, advertising design, operating characteristics, market strategies, cost accounting and profit target. It can guide students to make full use of the learning business knowledge, expand imagination, and carry out entrepreneurial design as an entrepreneur.

The simulation companies, operating procedures, or entrepreneurship teaching base complying with corporate behavior requirements should be established, which enable students to receive simulation train.

\section{Conclusions}

Focusing on the social demand for high-quality applied talents, this study proposed and practiced the entrepreneurial training model in the field of automotive services. The entrepreneurial talent training mode in local colleges are constructed and the innovative entrepreneurial training program is established implemented successfully by making the specialties of vehicle engineering and automotive service engineering in Linyi University as example. Through the research, it can prompt teachers to combine the course teaching and the innovative entrepreneurship ability cultivation closely to further enhance the scientific research ability and social services level. Through the implementation of entrepreneurial talent training programs, it can improve students, innovative spirit and entrepreneurial skills, cultivate the engineering consciousness, teamwork spirit of students, thus improve their overall quality, enhance professional capacity and employment adaptability.

\section{Acknowledgment}

This study was supported by the Teaching Research Project of Young Teachers of Shandong, China (No. 16SDJ211), the Teaching Reform Project of Linyi University(No. 2014016), and the Teaching Quality Engineering Project of Linyi University in 2014.

\section{References}

[1] B. Q. Liu, The Entrepreneurial Talent Producing Pattern of British Universities and Its Enlightenments, Journal of Higher Education Management. 8(1) (2014) 109-115.

[2] Z. X. Huang, E. L. Zeng, Y. C. Shi, J. Y. Zhou, New Strategy for Engineering Education in Local Universities: Engineering Talents Training Mode Integrating with Enterprise Education, Research in Higher Education of Engineering. (5) (2012) 137-141.

[3] F. B. Li, Z. L. Xu, Exploring the Model of Cultivation Innovation and Entrepreneurship Talents of Higher Education Institutions, Journal of Zhejiang University of Technology (Social Science). 12(3) (2013) 346- 349.

[4] H. Jiang, H. G. Yin, X. C. Xu, Research on the Mode of Cultivating Talents of Innovation and Entrepreneurship in Colleges and Universities, Journal of National Academy of Education Administration. (3) (2015) 27-31.

[5] L. H. Wei, Z. W. Chen, Mode of Entrepreneurial Education and Its development Tendency, Research in Teaching. 32(2) (2009) 39-43

[6] P.J. Chen. Study on the Modes of Resource Integration and Utilization of Foreign Schools and Enterprises, Education Management and Management Science, 7 (2015), 265 -268. 